(C) Elsevier/INRA

\title{
A comparison of genetic data from New Zealand and France on twin calving in cattle
}

\author{
CA Morris ${ }^{1}$, JL Foulley ${ }^{2 *}$ \\ 1 Ministry of Agriculture and Fisheries, Ruakura Agricultural Centre, PB, Hamilton, \\ New Zealand \\ 2 Institut National de la Recherche Agronomique, Station de Génétique Quantitative \\ et Appliquée, Équipe de Génétique Statistique, 78352 Jouy-en-Josas Cedex, France
}

(Received 21 March 1990; accepted 3 June 1991)

\begin{abstract}
Summary - Data on twin calvings were compared from New Zealand ( $1559^{\circ}$ cows in 3 selected private herds; two Milking Shorthorn and one Friesian) and France (216 cows in 11. Maine Anjou pedigree herds). Twin calving rates (France only) and cumulative numbers of twin calvings per lifetime (both countries) were obtained for all cows, classified according to their sire and dam groups. Dam groups were defined according to the number of twin calvings in the dam's lifetime. In New Zealand, the 2 sire groups were defined as follows : (1) no daughter producing 2 or more sets of twins; (2) at least one such daughter. In France, the discrimination was based on the twin calving rate of daughters recorded in the whole population with group 1 below $6 \%$ and group 2 over that value. The mean frequencies of cows with at least one set of twins were 0.112 in the New Zealand herds and 0.125 in France. In both countries, there were significant effects of sire and dam groups, but no interaction on a logit scale. In addition, the 2 data sets showed a similar increase $(\times 1.9$ to $\times 2.5)$ in frequency of cows producing at least 1 twin set comparing those from dams with twins and those from dams with no twin set. Resultats demonstrated the opportunity of sire selection to improve twin calving performance. The efficiency of selection would also be enhanced by a joint choice of sires dams from prolific groups.
\end{abstract}

cattle / twinning / genetics

Résumé - Une comparaison de données génétiques françaises et néo-zélandaises sur le taux de vêlages gémellaires des bovins. Cet article compare des données de vêlages gémellaires obtenues en Nouvelle-Zélande (1559 vaches de 3 élevages privés dont 2 de race laitières Shorthorn et 1 de race Frisonne) et en France (216 vaches provenant de 11 élevages de sélection de race Maine Anjou). On disposait du taux de vêlages gémellaires (en France seulement) et du nombre cumulé de vêlages gémellaires dans la carrière d'une vache et de leur répartition par groupe de pères et de mères. Les groupes de mères étaient définis selon le nombre de vêlages gémellaires observés au cours de la carrière de la vache.

* Correspondence and reprints 
En Nouvelle-Zélande, les 2 groupes de pères étaient définis selon que le père comportait (groupe 2) ou non (groupe 1) au moins une fille ayant produit au moins 2 fois des jumeaux. En France, la discrimination était basée sur le taux de vêlages gémellaires observés sur les filles contrôlées dans toute la population, le seuil entre les deux groupes se situant à $6 \%$. La fréquence de vaches ayant eu au moins une fois des jumeaux était de 0,112 en NouvelleZélande et 0,125 en France. Dans les 2 pays, on a mis en évidence des effets significatifs des groupes de pères et de mères, mais pas d'interaction sur une échelle logit. De plus, les 2 fichiers indiquaient des accroissements relatifs similaires des performances de gémellité entre filles issues de mères n'ayant eu aucun vêlage gémellaire et celles issues de mères avec au moins un vêlage gémellaire. Ces résultats prouvent l'intérêt d'une sélection des mâles pour améliorer le taux de vêlages gémellaires ainsi que celui d'un choix simultané de parents parmi les groupes les plus prolifiques.

bovins / jumeaux / génétique

\section{INTRODUCTION}

Recent studies of sire and dam group effects on twin calving in New Zealand (NZ) and in France (F) have led to similar findings (Foulley et al, 1990; Morris and Day, 1990). Both described the probability of obtaining twin calvings from daughters of different sire or dam groups. This was in spite of different twin calving rates per year in the 2 studies ( 0.031 and 0.077 in NZ and F respectively) and different breed composition (Milking Shorthorn and Friesian in NZ vs Maine Anjou in F).

\section{MATERIALS AND METHODS}

Data were taken from the 2 studies cited above. Briefly, the NZ data set described the lifetime incidence of twin calvings in 1559 cows from 2 Milking Shorthorn herds (calvings 1958-1987 and 1975-1987) and one Friesian herd (calvings 1973-1987). The overall twin calving rates per year were $0.030,0.031$ and 0.033 , compared with a national average for dairy herds of about 0.01 (New Zealand Dairy Board, 1961). There was a cumulative record of the number of twin calvings per lifetime for all cows, and pedigree available. Apart from twin calvings each year, the status of all other cows (calved or non-pregnant) was not recorded, so that twin calving rates on individual animals were not known.

The French data consisted of twin calving records on 680 calvings in 216 Maine Anjou cows from a total 11 herds involved in the nucleus of the high twinning selection programme set up in that breed.

In both data sets, cows were classified according to sire and dam groups as proposed originally by Morris and Day (1990). In New Zealand, sire group 1 included sires with no daughters producing 2 or more sets of twins and sire group 2 included those with at least 1 such daughter. In France, the classification of sires was based on the twin calving rate of daughters recorded in the whole population; sire below $6 \%$ were in group 1 and sires over that value were in group 2. Dam group (i) consisted of cows from dams with no calvings in their lifetime, and dam group (ii) consisted of cows from dams with 1 twin calvings or $\geq 2$ twin calvings in their lifetime. The categories for 1 and $\geq 2$ calvings were kept separate in the NZ data, but were combined in the smaller French data set. Allowance for ascertainment in 
defining sire group 2 was made in the NZ file by discarding the record of the first twice-twinning daughter used to classify a sire as group 2 .

Within-country analyses of effets due to sire and dam groups were reported by Morris and Day (1990) and Foulley et al (1990). The comparisons made here were effects of sire groups 2 relative to sire group 1, and of dam group (ii) relative to dam group (i) for both countries. The traits analysed were the proportion $(t)$ of cows producing at least 1 twin set in a lifetime (NZ and F), and additionally the proportion $(v)$ of cows producing a twin set per calving (French data only).

\section{RESULTS}

Table I shows the effects of sire group and dam group on the proportion $t$ for both countries and the proportion $v$ for France. The value $v$ (known for all animals in the NZ data) was 0.031 vs 0.077 for France. In contrast, mean values overall for $t$ were similar : 0.112 for $\mathrm{NZ}$ (or 0.098 after allowing for ascertainment) and 0.125 for $F$ data. However, this similarity is mainly due to a balance between 2 opposite effects : $v$ values smaller in NZ than in $\mathrm{F}$ but number of calvings larger in NZ than in $\mathrm{F}$ ( 5 vs 3 on average respectively). Differences in repeatability between countries may also occur, although they are likely to be small; in the 4 selected private herds studied by Morris and Day (1990), only $18 \%$ of cows with a twin calving had a second or latter twin set; Foulley et al (1990) using records on twinning of Charolais and Maine Anjou cows prior to purchase in farms, and after purchase in an experimental herd found a realized repeatability of 0.05 .

Significant effects of sire group and dam on $t$ were reported by Morris and Day (1990). The same conclusion can be drawn for $t$ and $v$ from the statistical analysis made with French data using a logit transformation (see table II). Table III shows the relative increase in $t$ or $v$ values from dam groups (i) and (ii) and from sire groups 1 and 2 . The relative increases in $t$ appeared to be consistent for dams groups between countries, although the mean twinning rates were quite different. Overall, the relative increases in $t$ were 1.9 and 2.5 between dam lifetime twinning groups in NZ and $\mathrm{F}$ data, respectively.

The relative increases were however smaller between sire groups 1 and 2 in $\mathrm{NZ}$ (average 1.8) than in France (average 6.2). Although breed composition and environmental factors may be involved, this difference mainly reflects the difference in discriminating the 2 groups of bulls between countries. The French classification of sires based on extra field records (than those recorded on the 11 herds studied) results in a larger genetic divergence among true genetic merits of bulls. Actually, the effects of sire and dam groups on $v$ appear to be purely multiplicative in the French data set : dams $\geq 1$ dams $0=2.5$ irrespective of the sire group and sires $2 /$ sires $1=5$ irrespective of the dam group (table III).

\section{DISCUSSION}

The absence of interaction between sire and dam groups found in both data sets (table II) legitimatizes the use of an additive model to describe the genetic relationship between parents and progeny on a logit scale. Because the cumulative 
Table I. Effect of sire group and dam group on the lifetime or annual twinning rate ${ }^{\mathrm{a}}$ of cows in 3 New Zealand herds and a Maine-Anjou cows in France.

\begin{tabular}{|c|c|c|c|c|c|c|c|}
\hline \multirow{2}{*}{$\begin{array}{l}\text { Sire } \\
\text { group }\end{array}$} & \multirow[t]{2}{*}{ Country } & \multirow[t]{2}{*}{ Item } & \multicolumn{5}{|c|}{ Lifetime twin sets from the dam } \\
\hline & & & 0 & 1 & & $>1$ & Total \\
\hline 1 & NZ & $\begin{array}{l}N \\
t \\
v\end{array}$ & $\begin{array}{c}837 \\
\mathbf{0 . 0 7 0} \\
\\
152 \\
\mathbf{0 . 0 5 9} \\
0.032\end{array}$ & $\begin{array}{c}123 \\
0.098\end{array}$ & $\begin{array}{c}\mathbf{0 . 1 0 7} \\
28 \\
\mathbf{0 . 1 0 7} \\
0.081\end{array}$ & $\begin{array}{c}54 \\
0.130\end{array}$ & $\begin{array}{c}1014 \\
0.077 \\
\\
180 \\
0.067 \\
0.038\end{array}$ \\
\hline 2 & $\mathrm{NZ}$ & $\begin{array}{l}N \\
t \\
v\end{array}$ & $\begin{array}{c}426(18)^{\mathrm{d}} \\
\mathbf{0 . 1 1 3} \\
\\
28 \\
\mathbf{0 . 3 2 1} \\
0.164\end{array}$ & $\begin{array}{l}72(4) \\
0.222\end{array}$ & $\begin{array}{c}0.263 \\
8 \\
0.750 \\
0.410\end{array}$ & $\begin{array}{l}23(2) \\
0.391\end{array}$ & $\begin{array}{c}521(24) \\
0.140 \\
\\
36 \\
\mathbf{0 . 4 1 7} \\
0.206\end{array}$ \\
\hline Total & $\mathrm{NZ}$ & $\begin{array}{l}N \\
t \\
v\end{array}$ & $\begin{array}{c}1263(18) \\
\mathbf{0 . 0 8 5} \\
\\
180 \\
\mathbf{0 . 1 0 0} \\
0.061\end{array}$ & $\begin{array}{c}195(4) \\
0.144\end{array}$ & $\begin{array}{c}0.162 \\
36 \\
0.250 \\
0.180\end{array}$ & $\begin{array}{l}77(2) \\
0.208\end{array}$ & $\begin{array}{c}1535(24) \\
\mathbf{0 . 0 9 8}^{\mathrm{e}} \\
\\
216 \\
\mathbf{0 . 1 2 5} \\
0.077\end{array}$ \\
\hline
\end{tabular}

a Lifetime twin calving rate $(t)=$ proportion of cows calving at least one set of twins in a lifetime; annual twin calving rate $(v)=$ proportion of cows producing a twin set per calving. ${ }^{b} \mathrm{NZ}$ : size group $1=$ sires with no daughters producing 2 or more sets of twins; sire group 2 : sires with at least one such daughter; F; sire group $1=$ sires with twinning rate in daughters below $6 \%$; sire group $2=$ sires above $6 \%$. ${ }^{c} N=$ number of cow lifetimes. ${ }^{d}$ Numbers in brackets are those excluded due to ascertainment in classifying group 2 sires. ${ }^{\mathrm{e}}$ Ignoring ascertainment, the overall mean value for $t$ was 0.112 . A value for $v$ overall was known in the NZ herds $(0.031)$.

normal and the logit distribution are very close, this result supports the assumption of additive genetic determinism on an underlying normal liability scale as postulated by several authors (Gregory et al, 1990; Ron et al, 1990; Manfredi et al; 1991). Theoretically, this does not preclude the existence of a major gene provided its effects are additive, although the assumption of a purely additive polygenic model would be just as relevant in such a case. In fact, most recent studies testing for the presence of a major gene segregating for twin calving rate in cattle, $i e$ in Norway (Syrstad, 1984), Israel (Ron et al, 1990), USA (Gregory et al, 1990), New Zealand (Morris and Day, 1990) have as yet been unsuccessful.

Nevertheless, the important increase in twinning performance due to using group 2 vs group 1 sires (ranging from 1.8-6.2) highlights the opportunity of sire selection to increase twinning performance as already stressed by several authors eg Johansson et al (1974), Maijala and Syväjärvi (1977), Gregory et al (1990), Ron 
Table II. Analysis of deviance for sire and dam group effects on twin calving performance in 3 New Zealand and one French herds.

\begin{tabular}{|c|c|c|c|c|c|c|c|c|}
\hline \multirow[t]{3}{*}{ Source } & \multicolumn{3}{|c|}{ New Zealand ${ }^{\mathrm{a}}$} & \multicolumn{5}{|c|}{ France } \\
\hline & \multicolumn{3}{|c|}{$t^{\mathrm{b}}$} & \multicolumn{3}{|c|}{$t^{\mathrm{b}}$} & \multicolumn{2}{|c|}{$v^{\mathrm{b}}$} \\
\hline & $d f^{\mathrm{c}}$ & $\chi^{2^{\mathrm{d}}}$ & $P^{\mathrm{e}}$ & $d f^{\mathrm{c}}$ & $\chi^{2^{d}}$ & $P^{\mathbf{e}}$ & $\chi^{2^{\mathrm{d}}}$ & $P^{\mathrm{e}}$ \\
\hline Sire & 1 & 15.46 & $<0.0001$ & 1 & 24.87 & 0.0001 & 36.33 & 0.0001 \\
\hline Dam & 2 & 15.38 & $<0.001$ & 1 & 4.60 & 0.03 & 10.74 & 0.001 \\
\hline$S \times D^{\mathrm{f}}$ & 2 & 3.08 & 0.20 & 1 & 1.17 & 0.17 & 0.17 & 0.68 \\
\hline
\end{tabular}

${ }^{\text {a}}$ From Morris and Day (1990), (table VI) including an adjustement for herd effects. ${ }^{\mathrm{b}} t=$ Lifetime twin performance and $v=$ twin calving rate as defined in table I. ${ }^{\mathrm{c}}$ Degrees of freedom : ${ }^{\mathrm{d}} \chi^{2}$ reduction; ${ }^{\mathrm{e}}$ probability that a $\chi^{2}$ distribution with $d f$ degrees of freedom exceeds the value observed; ${ }^{f}$ sire by dam group interaction.

Table III. Relative rates of twin calving in different genetic groups in New Zeland and in France ${ }^{\mathrm{a}}$.

\begin{tabular}{lccc}
\hline $\begin{array}{l}\text { Genetic group and criterion } \\
\text { for subdivision }\end{array}$ & $t$ & \multicolumn{2}{c}{ France } \\
\hline Dams : twins $\geq 1$ vs 0 & & & $v$ \\
$\quad$ Sire group 1 & 1.53 & 1.81 & 2.49 \\
Sire group 2 & 2.33 & 2.33 & 2.48 \\
All & 1.91 & 2.50 & 2.95 \\
Sires : group 2 vs 1 & & & \\
Dam lifetime : 0 twins & 1.61 & 5.43 & 5.06 \\
Dam lifetime : $\geq 1$ twin sets & 2.46 & 7.00 & 5.05 \\
All & 1.82 & 6.25 & 5.42 \\
\hline
\end{tabular}

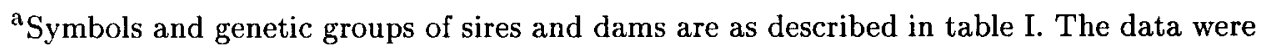
also obtained from table $\mathrm{I}$. The relative rate of twin calving showns the relative frequency in the 2 dam categories, or in the 2 sire categories.

et al (1990), and Manfredi et al (1990, 1991). Moreover, efficiency of selection is clearly enhanced by a joint choice of sires and dams as shown by $t$ and $v$ values obtained in mating group 2 sires with dams having at least one set of twins. Such results may be exploited in pratice both for experimental purpose and for breeding programmes.

\section{ACKNOWLEDGMENTS}

The authors wish to thank the New Zealand farmers and French Maine Anjou breeders whose herds are involved in this study. They are also grateful to M Poutous (INRA, Jouy) for his critical reading of the manuscript. 


\section{REFERENCES}

Foulley JL, Gillard P, Manfredi EJ (1990) Le programme de Recherche et Développement de l'INRA-Génétique Animale sur la Gémellité (unpublished mimeo)

Gregory KE, Echternkamp SE, Dickerson GE, Cundiff LV, Koch RM, Van Vleck LD (1990) Twinning in cattle : I. Foundation animals and genetic and environmental effects on twinning rate. J Animal Sci 68, 1867-1876

Johansson I, Lindhé B, Pirchner F (1974) Causes of variation in the frequency of monozygous and dizygous twinning in various breeds of cows. Hereditas 78, 201-234 Maijala K, Syväjärvi J (1977) On the possibility of developing multiparous cattle by selection. Z Tierzüchtg Züchtgsbiol 94, 136-150

Manfredi EJ, San Cristobal M, Foulley JL, Gillard P, Valais A (1990) Genetic analysis of twinning in the Maine Anjou breed. In : 41th Ann Meet EAAP, Toulouse, France, July 9-12 1990, vol 1, 114 abstr

Manfredi EJ, Foulley JL, San Cristobal M, Gillard P (1991) Genetic parameters for twinning in the Maine Anjou breed. Genet Sel Evol 23 (in press)

Morris CA, Day AM (1990) Effects of dam and sire group on the propensity for twin calving in cattle. Anim Prod 51, 481-488

New Zealand Dairy Board (1961) 37th Farm Prod Rep, Farm Production Division NZ Dairy Board Wellington, NZ

Ron M, Ezra E, Weller JI (1990) Genetic analysis of twinning rate in Israeli Holstein cattle. Genet Sel Evol 22, 349-359

Syrstad O (1984) Inheritance of multiple births in cattle. Livest Prod Sci 11, 373-380 